\title{
Abbreviations
}

\section{Citations of Kant's Writings}

Ak Immanuel Kants Schriften. Ausgabe der königlich preussischen Akademie der Wissenschaften (Berlin: W. de Gruyter, I902), cited by volume:page number in this edition

$\mathrm{Ca} \quad$ Cambridge Edition of the Writings of Immanuel Kant (New York: Cambridge University Press, I992-2016); this edition provides marginal Ak volume:page citations

Anth Anthropologie in pragmatischer Hinsicht (I798), Ak 7 Anthropology from a Pragmatic Point of View, Ca Anthropology, History, and Education

BM Von der Buchmacherei ( I797), Ak 8

On Turning Out Books, Ca Anthropology, History, and Education

G Grundlegung zur Metaphysik der Sitten (1785), Ak 4 Grundlegung zur Metaphysik der Sitten (I785-86), edited by Bernd Kraft and Dieter Schönecker (Hamburg: Felix Meiner Verlag, 1999)

I Idee zu einer allgemeinen Geschichte in weltbürgerlicher Absicht ( 1784 ), Ak 8

dea Toward a Universal History with a Cosmopolitan Aim, $\mathrm{Ca}$ Anthropology, History, and Education

$\mathrm{KpV} \quad$ Kritik der praktischen Vernunft (I788), Ak 5 Critique of Practical Reason, Ca Practical Philosophy

$\mathrm{KrV} \quad$ Kritik der reinen Vernunft (I78 I, I787), cited by A/B pagination

Critique of Pure Reason, Ca Critique of Pure Reason

KU Kritik der Urteilskraft (1790), Ak 5

Critique of the Power of Judgment, Ca Critique of the Power of Judgment

MA Mutmaßlicher Anfang der Menschengeschichte (I786), Ak 8 
Conjectural Beginning of Human History, Ca Anthropology, History and Education

MS Metaphysik der Sitten (I797-I798), Ak 6 Metaphysics of Morals, Ca Practical Philosophy

O Was heißt: Sich im Denken orientieren? (I786), Ak 8 What Does It Mean to Orient Oneself in Thinking? Ca Religion and Rational Theology

P Prolegomena zu einer jeden künftigen Metaphysik (I783), Ak 4 Prolegomena to Any Future Metaphysics, Ca Theoretical Philosophy After I $78 \mathrm{I}$

$\mathrm{R} \quad$ Religion innerhalb der Grenzen der bloßen Vernunft (I794), Ak 6

Religion Within the Boundaries of Mere Reason, Ca Religion and Rational Theology

RH Rezensionen von Herders Ideen zu einer Philosophie der Geschichte der Menschheit (I785-86), Ak 8 Reviews of Herder's Ideas for a Philosophy of History of Humanity, Ca Anthropology, History, and Education

TP Über den Gemeinspruch: Das mag in der Theorie richtig sein, taugt aber nicht für die Praxis (I793), Ak 8

On the Common Saying: That May Be Correct in Theory but It Is of No Use in Practice, Ca Practical Philosophy

VE Coll Vorlesungen über Ethik Moralphilosophie Collins, Ak 27 Lectures on Ethics, Ca Lectures on Ethics

VE Mro Vorlesungen über Ethik Moralphilosophie Mrongovius, Ak 27 Lectures on Ethics, Ca Lectures on Ethics

$\mathrm{VL} \quad$ Vorlesungen über Logik, Ak 9 Lectures on Logic, Ca Lectures on Logic 


\section{Formulas of the Moral Law}

Kant formulates the moral law in three principal ways. The first and third of these have variants which are intended to bring the law "closer to intuition" and make it easier to apply. These five principal formulations of the moral law will be abbreviated as follows.

First formula:

FUL The Formula of Universal Law: "Act only in accordance with that maxim through which you at the same time can will that it become a universal law" (G 4:42 I; cf. G 4:402), with its variant,

FLN The Formula of the Law of Nature: "So act, as if the maxim of your action were to become through your will a universal law of nature" (G 4:42 I; cf. G 4:436).

Second formula:

FH The Formula of Humanity as End in Itself: "So act that you use humanity, as much in your own person as in the person of every other, always at the same time as an end and never merely as a means" (G 4:429; cf. G 4:436).

Third formula:

FA Formula of Autonomy: ". . . the idea of the will of every rational being as a will giving universal law" (G 4:43 I; cf. $\mathrm{G} 4: 432$ ) or "Not to choose otherwise than so that the maxims of one's choice are at the same time comprehended with it in the same volition as universal law" (G 4:440; cf. G 4:432, 434, 438), with its variant,

FRE The Formula of the Realm of Ends: "Act in accordance with maxims of a universally legislative member for a merely possible realm of ends" (G 4:439; cf. G 4:433, 437, 438). 
This page intentionally left blank 